\title{
Mayfield head clamp and intracranial epidural hematoma
}

\author{
Miguel Gelabert-González • Ramón Serramito-García
}

Received: 4 May 2010/Accepted: 27 December 2010/Published online: 12 January 2011

(C) Springer-Verlag 2011

\section{Dear Editor,}

Having read with interest, the recent paper by Lee and Lin [1], "The use of the three-pronged Mayfield head clamp resulting in an intracranial epidural hematoma in an adult", we would like to make a few observations based on our previously experience [2].

Firstly, the authors said that "intracranial epidural hematomas related to the use of Mayfield has not been published in adults". We recently published the case of a 19 -year-old young admitted for a endoscopic third ventriculostomy who developed an epidural hematoma due to the penetration of the skull by a pin, and review the complications in adult patients, resulting from the use of this type of head holder and found other similar two cases in patients 23 and 24 years of age [3, 4].

Second, the neurosurgeons know the importance of correct positioning of the pins; in the case described by Lee and Lin [1], we can see that the pin was placed on the temporal squama and in this location the skull can be very thin, and should be avoided as possible skull-clamp pin-location sites.
And finally, in our case, the epidural hematoma and the perforation of the skull were placed on the parietal bone, which was very thin due to the chronic intracranial hypertension of the patient [2].

Conflict of interest None.

\section{References}

1. Lee MJ, Lin EL (2010) The use of the three-pronged Mayfield head clamp resulting in an intracranial epidural hematoma in an adult. Eur Spine $\mathbf{J}$ (epub ahead of print)

2. Serramito-García R, Arcos-Algaba A, Santín-Amo JM, GarcíaAllut A, Bandín-Diéguez FJ, Gelabert-González M (2009) Epidural hematoma due to an headrest in an adult. Neurocirugía 20:567-750

3. Erbayraktar S, Gömen N, Acar Ü (2001) Intracranial penetrating injury associated with an intraoperative epidural haematoma caused by a spring-laden pin of a multipose headrest. $\mathrm{Br} \mathrm{J}$ Neurosurg 15:425-428

4. Sade B, Mohr G (2005) Depressed skull fracture and epidural hematoma: an unusual post-operative complication of pin headrest in a adult. Acta Neurochir (Wien) 147:101-103
M. Gelabert-González $(\bowtie) \cdot$ R. Serramito-García Department of Surgery, School of Medicine,

University of Santiago de Compostela,

San Francisco 1, 15705 Santiago de Compostela, Spain

e-mail: miguel.gelabert@usc.es 